\title{
Críticos y rebeldes en América del Sur. Prensa, redes de interacción y debate político en la formación de la opinión pública moderna en tiempos de la independencia (1810-1822)*
}

Luis Daniel Morán Ramos

\begin{abstract}
Docente investigador de la Universidad San Ignacio de Loyola (Perú).Correo electrónico: luis.moranr@usil. pe. El autor es doctor en historia de la Universidad de Buenos Aires (Argentina). Entre sus publicaciones recientes tenemos: "Construyendo al enemigo. La emergencia de identidades políticas y las representaciones del otro en la prensa hispanoamericana en los tiempos de la Independencia", Temas Americanistas, $\mathrm{N}^{\circ} 39$ (2017) y "El mundo de los impresos y los discursos políticos en el Perú. La prensa en la experiencia de las Cortes de Cádiz y el ciclo revolucionario en América”. En Chust Manuel y Claudia Rosas (eds.), El Perú en Revolución. Independencia y guerra: un proceso, 1780-1826. España: Universitat Jaume I-El Colegio de Michoacán-PUCP, 2017. Entre sus temas de interés están: la historia política y cultural de América Latina, y la historia de la prensa y los medios de comunicación en los tiempos de la independencia.
\end{abstract}

Recibido: 20 de octubre de 2017

Aprobado: 5 de febrero de 2018

Modificado: 15 de febrero de 2018

Artículo de investigación científica

DOI: http://dx.doi.org/10.15648/hc.34.2019.1

Este artículo forma parte del primer capítulo de la tesis doctoral: Daniel Morán, "La revolución y la guerra de propaganda en América del Sur. Itinerarios políticos de la prensa en Lima, Buenos Aires y Santiago de Chile (1810-1822)", (tesis de Doctor en Historia, Facultad de Filosofía y Letras, Universidad de Buenos Aires, 2017), financiado por el CONICET (Argentina) y la Universidad San Ignacio de Loyola (Perú).

Esta publicación está bajo una licencia Creative Commons Reconocimiento-NoComercial 4.0 
Críticos y rebeldes en América del Sur. Prensa, redes de interacción y debate político en la formación de la opinión pública moderna en tiempos de la independencia (1810-1822).

\title{
Resumen
}

En el contexto del bicentenario de las independencias esta investigación tiene como objetivo central analizar la participación y la interacción de los escritores públicos en el debate político y en la formación de la opinión pública moderna a través de los discursos políticos de la prensa en Lima, Buenos Aires y Santiago de Chile desde la revolución de mayo (1810) hasta el Protectorado del General José de San Martín en el Perú (1821-1822). En ese sentido, estos críticos y rebeldes de los diversos espacios estudiados intervinieron en la experiencia de la revolución del impreso y en la guerra de propaganda desatada en perspectiva continental buscando la legitimidad política en tiempos de revolución e independencia.

Palabras clave: Independencia, prensa, escritores públicos, debate político, opinión pública, batallas por la legitimidad.

Critics and rebels in South America. Press, interaction networks and political debate in the formation of modern public opinion in times of Independence (1810-1822).

\begin{abstract}
In the context of the bicentennial of the Independences, this research aims to analyse the participation and interaction of public writers in the political debate and in the formation of modern public opinion through the speeches press politicians in Lima, Buenos Aires and Santiago de Chile from the May Revolution (1810) to the Protectorate of General Jose de San Martín in Peru (1821-1822). In this sense, these critics and rebels of the various spaces studied intervened in the experience of the revolution of the print and in the propaganda war unleashed in continental perspective seeking political legitimacy in times of revolution and Independence.
\end{abstract}

Key words: Independence, press, public writers, political debate, public opinion, battles for legitimacy. 
Críticos e rebeldes na América do Sul. Imprensa, redes de interação e discussão política na formação da opinião pública moderna nos tempos da independência (1810-1822).

\section{Resumo}

No contexto do bicentenário das independências essa pesquisa tem como objetivo principal analisar a participação e interação dos escritores públicos nas discussões políticas e na formação da opinião pública moderna através dos discursos políticos da imprensa de Lima, Buenos Aires e Santiago do Chile desde a revoluçáo de Maio (1810) até o protectorado do general José de San Martín no Peru (1821-1822). Nesse sentido, estes críticos e rebeldes dos distintos espaços estudados intervieram na experiência da revoluçáo do impresso e na guerra de propaganda desencadeada em abordagem continental buscando a legitimação política nos tempos de revolução e independência.

Palavras-chave: independência, imprensa, escritores, públicos, discussão política, opinião pública, batalhas pela legitimidade.

Critiques et rebelles en Amérique du Sud. Presse, réseaux d'interaction et débat politique dans la formation de l'opinion publique moderne aux temps de l'indépendance (1810-1822).

\section{Résumé}

Dans le contexte du bicentenaire des indépendances, cette recherche a pour objectif central d'analyser la participation et l'interaction des écrivains publiques dans le débat politique et dans la formation de l'opinion publique moderne à travers des discours politiques de la presse à Lima, Buenos Aires et Santiago de Chili depuis la révolution de mai (1810) jusqu’au Protectorat du Général José de San Martín au Pérou (1821-1822). Dans ce sens, ces critiques et rebelles de diverses espaces étudiés, ont intervenu dans l'expérience de la révolution de l'imprimé et dans la guerre de propagande éclatée en perspective continentale, laquelle cherchait la légitimité politique aux temps de révolution et indépendance.

Mots clés: indépendance, presse, écrivains publiques, débat politique, opinion publique, batailles pour la légitimité. 


\section{INTRODUCCIÓN}

"Sería inútil recomendar la utilidad de los periódicos, habiéndola hecho perceptible el uso constante de las naciones cultas los prodigiosos efectos que refiere la experiencia, y los grandes encomios que de ellos leemos en los escritores sabios y filósofos. Basta conocer su objeto para penetrarse de su importancia. Este no es otro que la introducción de las luces y la corrección de los abusos [...] Ningún periódico es más a propósito que llenar este inexplicable interés que el INVESTIGADOR; porque saliendo todos los días, y siendo tan corta su extensión, aun los que desgraciadamente son rivales de toda clase de lectura por ocio o por genio, no dejarán de instruirse en lo que deban obrar y en lo que merece reforma, ya sea aplicando la vista por pasatiempo, o escuchando su contenido en las conversaciones de sus conciudadanos.

En el orden político, el conocimiento del mal es un principio de su destrucción. La capital del Perú logra desde luego, algún tanto esta ventaja; pero absolutamente carecen de ella todas sus provincias y partidos, que acaso necesitan más del vehículo saludable de la imprenta para disipar sus tinieblas, y extirpar los abusos que los oprimen, estrellándolos contra la opinión pública, que es un tribunal más temible que las huestes extranjeras. [...] Los cabildos con más particularidad, deben ocurrir a esta grande obra. De este modo los diputados a cortes por el Cuzco y todos sus partidos, por Arequipa y los suyos, por Trujillo, Guayaquil, Tarma, Huamanga, Huancavelica, etc., se hallarán insensiblemente con las instrucciones hechas para promover en la soberanía su felicidad; y en fin, este periódico vendrá a ser para todos aquellos pueblos, que carecen de imprentas, el órgano por donde le comuniquen al mundo sus pensamientos hasta boy soterrados en la oscuridad de sus aisladas mansiones"1.

22 Este extenso discurso de El Investigador de 1813 ejemplifica la importan-

1 El Investigador, No 29, Lima, lunes 29 de noviembre de 1813. 
cia de la prensa y los escritores públicos en el escenario político de las guerras de independencia. En el texto se advierte "la utilidad de los periódicos" producto de los "escritores sabios y filósofos" que buscan "la introducción de las luces" convirtiendo a la opinión pública en "un tribunal más temible que las huestes extranjeras"2. Incluso, como se advierte en el periódico los impresos circulan por una amplia red de comunicación y espacios públicos de socialización que comunican al mundo, el pensamiento de estos hombres de letras denominados escritores públicos, gaceteros, panfletistas, etc ${ }^{3}$.

No obstante, la prensa, a pesar de su propagación por los espacios públicos y las diversas redes de comunicación, tuvo en sus inicios un carácter urbano, de sectores ilustrados y un claro componente político ${ }^{4}$. Pero si bien su vinculación con el poder durante las guerras de independencia fue una realidad permanente, en el mismo proceso de la guerra, en el debate y en las interacciones públicas de estos escritores u hombre de letras, la politización de sus discursos y la propagación de sus escritos tuvo un alcance social

2 Sobre el concepto de opinión pública véase: Eugenia Molina, El poder de la opinión pública. Trayectos y avatares de una nueva cultura política en el Río de la Plata, 1800-1852 (Santa Fe: Universidad Nacional del Litoral, 2009), François-Xavier Guerra, "Voces del pueblo. Redes de comunicación y orígenes de la opinión en el mundo hispánico (1808-1814)", Revista de Indias vol. LXII, no 225 , mayo-agosto (2002): 357-384; y, Joelle Chassin, "Lima, sus elites y la opinión durante los últimos tiempos de la colonia”, en Los espacios públicos en Iberoamérica, eds. François-Javier Guerra y Annick Lempériére (México: FCE, 1998): 241-269.

3 Entendemos por escritores públicos a los hombres de letras e ilustrados americanos que escriben en los periódicos, gacetas, impresos, pasquines, etc., y que tienen un poder de interacción ideológica y política en los tiempos de la independencia. Estos escritores públicos serían la génesis de lo que llamaríamos a mediados del siglo XIX periodistas. Para una explicación detenida véase: Daniel Morán, Batallas por la legitimidad. La prensa de Lima y de Buenos Aires durante las guerras de independencia (Lima: Fondo Editorial de la Universidad de Ciencias y Humanidades, 2013); y, César Luis Díaz, Comunicación y revolución, 1759-1810. Esfera y espacio público rioplatense. Periodismo, censura, prácticas y ámbitos de lectura (La Plata: Ediciones de Periodismo y Comunicación, 2012). Además, resulta útil mencionar, a pesar de no ser la materia central de estudio, la participación de Jaime Bauzate y Meza en la prensa inicial del siglo XVIII: Jean-Pierre Clément, "Aproximación al Diario de Lima (1790-1793) y a Jaime Bausate y Mesa, su autor”, El Argonauta Español 3 (2016) y Carlos Cornejo, "Las gacetas y el Semanario Crítico en el Perú colonial del siglo XVIII", Cultura 26 (2012): 57-98.

4 Para una aproximación a la temática, consultar: Daniel Morán, Batallas por la legitimidad.; Ascensión Martínez Riaza, La prensa doctrinal en la independencia de Perú, 1811-1824 (Madrid: Ediciones Cultura Hispánica-Instituto de Cooperación Iberoamericana, 1985); Claudia Rosas Lauro, Del trono a la guillotina: El impacto de la revolución francesa en el Perú (1789-1808) (Lima: PUCP-IFEA-Embajada de Francia, 2006); y Silvana Carozzi, Las filosofías de la revolución. Mariano Moreno y los jacobinos rioplatenses en la prensa de Mayo, 1810-1815 (Buenos Aires: Prometeo, 2011). 
más amplio 5 . Además, la prensa como tribuna política, expresión de las tendencias ideológicas de los grupos de poder, fue desarrollada por hombres políticos convertidos en escritores públicos, atentos a las vicisitudes de los acontecimientos externos y las problemáticas que todo ello conllevó a la situación interna de las regiones americanas. Así, la relación existente entre la prensa, el poder político y los hombres que escriben en ella permite visualizar el ideario político de los periódicos y la participación de estos escritores públicos en la configuración política de sus respectivos Estados. ${ }^{6}$

En el prólogo de un estudio dedicado a rescatar los escritos y las ideas de los hombres de la revolución de mayo, Noemí Goldman ha señalado la necesidad de precisar que "no hubo 'un pensamiento de mayo' con ideas claras y definidas que habría preparado la revolución, sino un conjunto de circunstancias cambiantes dentro de una compleja trama política y militar que afectó al conjunto de los territorios" de la monarquía española. Efectivamente, este argumento refleja una realidad del proceso de la revolución que nos sugiere no uniformizar a diversos pensadores de estas luchas políticas cuando es obvio que sus ideas, muchas de ellas contradictorias, estuvieron sumergidas en esa serie de prácticas y conflictos por el poder y la autoridad del nuevo orden social surgido de la revolución. Y, será la prensa, un medio que no escape a esta problemática de la esfera del poder ${ }^{7}$. Este argumento del caso rioplatense puede advertirse claramente en la realidad de los escritores públicos de Lima y de Santiago de Chile en el proceso independentista. Entonces, no existe un pensamiento monolítico, sino un

5 Ascensión Martínez Riaza, La prensa doctrinal en la independencia de Perú, 61-68; Nancy Calvo, "Voces en pugna. Prensa política y religión en los orígenes de la república argentina", Hispania Sacra Vol. 122 (2008): 576-580.

6 Para un alcance teórico y metodológico sobre el tema véase: Roger Chartier, El mundo como representación. Estudios sobre historia cultural (Barcelona: Editorial Gedisa S.A., 1992); Robert Darnton, Los best sellers prohibidos en Francia antes de la revolución (Buenos Aires: FCE, 2008); y, François-Xavier Guerra, Modernidad e independencias (Madrid: Editorial MAPFRE, S.A., 1992). Un caso práctico de estos espacios vinculando prensa, discursos e identidades políticas puede consultarse: Daniel Morán, "Construyendo al enemigo. La emergencia de identidades políticas y las representaciones del otro en la prensa hispanoamericana en los tiempos de la Independencia", Temas Americanistas, $\mathrm{N}^{\circ} 39$ (2017): 113-145.

247 Noemí Goldman, "Legitimidad, soberanía e independencia en el pensamiento de Mayo", en El pensamiento de los hombres de Mayo, comp., Ricardo Tito (Buenos Aires: Editorial Ateneo, 2009), 7-17; Noemí Goldman, "Libertad de imprenta, opinión pública y debate constitucional en el Río de la Plata (1810-1827)", Prismas 4 (2000): 10-15. 
conjunto de discursos relacionados a intereses diversos y en estrecha vinculación a las luchas por la legitimidad política en tiempos de revolución.

En ese sentido, esta investigación analiza la participación y la interacción de los escritores públicos en el debate político y en la formación de la opinión pública moderna a través de los discursos políticos de la prensa en Lima, Buenos Aires y Santiago de Chile desde la revolución de mayo (1810) hasta el Protectorado del General José de San Martín en el Perú (1821-1822). La experiencia de comparar y especialmente vincular estos espacios y capitales del poder político evidencia una propuesta de historia conectada de la prensa en América y en una coyuntura histórica precisa: la de las pugnas políticas por la legitimidad del poder ${ }^{8}$. En esa perspectiva, este trabajo desarrolla el análisis de la temática en tres partes vinculantes: el de los escritores públicos de Lima, los jacobinos rioplatenses, y los liberales y patriotas de Santiago de Chile. Finalmente, a partir de estas experiencias, la investigación sostiene una propuesta de reflexión en conjunto del papel de la prensa y los hombres de letras o escritores públicos en estos espacios políticos convulsionados por el fuego de la revolución y la independencia?

\section{De PANFletarios, REFORMISTAS y ESCRITORES PÚBlicos EN LIMA.}

En el Perú, la instalación de las Cortes de Cádiz y la formación de juntas insurgentes en América propiciaron la aparición de La Gaceta del Gobierno de Lima en octubre de 1810. En la dirección y la redacción de aquel importante periódico oficial del régimen colonial estuvieron José Pezet y Gregorio Paredes ${ }^{10}$. En las páginas de La Gaceta de Lima se percibe una abierta crítica a los movimientos revolucionarios porteńos y a las acciones disidentes de las otras regiones insurrectas. Si tuviéramos que destacar una figura principal en este periódico, indudablemente, deberíamos pensar en el virrey Abascal y en los citados directores, además de las aportaciones de Félix Devoti y José Joaquín de Larriva ${ }^{11}$.

8 Sanjay Subrahmanyam. "Connected Histories: Notes towards a Reconfiguration of Early Modern Eurasia”, Modern Asian Studies, Vol. 31,No. 3 (1997): 735-762.

9 Para un balance historiográfico reciente de las independencias véase: Manuel Chust (ed.), Las independencias iberoamericanas en su laberinto (Valencia: Universidad de Valencia, 2010); y, Heraclio Bonilla (ed.), La Constitución de 1812 en Hispanoamérica y España (Bogotá: Universidad Nacional de Colombia, 2012).

10 La Gaceta de Gobierno de Lima. № 1, sábado 13 de octubre de 1810.

11 Daniel Morán, "Reformistas, fidelistas y contrarrevolucionarios. Prensa, poder y discurso político en 
Precisamente este último, clérigo con una tendencia liberal moderada, fue uno de los principales animadores de la prensa constitucionalista del período revolucionario. Larriva aparte de publicar en La Gaceta de Lima, fue el director y redactor de El Investigador, periódico que circuló por la capital y gran parte del virreinato peruano entre 1813 y $1814^{12}$. Este periódico fue un impreso político auspiciado por el gobierno colonial que quiso presentarse como un periódico imparcial en abierto debate con La Gaceta de Lima y más relacionado a los problemas de la ciudad y de las clases populares $^{13}$. Raúl Porras Barrenechea señaló que el principal promotor del periódico fue "un conspirador de palabra [y un] haragán con sueldo del Estado" ${ }^{14}$. Además, en nuestras propias investigaciones, hemos indicado cómo desde la llegada de Abascal a Lima en 1806, Larriva manifestó su apoyo incondicional a la máxima autoridad. Incluso, durante los acontecimientos de la invasión francesa de España, la experiencia de las Cortes de Cádiz y los movimientos insurgentes en las colonias, el creador de El Investigador llegó a calificar al virrey como "el hombre de la América"15. Igualmente, en el propio discurso del periódico se puede observar esta premisa a partir del análisis de las fuertes críticas que realizó al Cabildo, la Audiencia y la Inquisición, instituciones que mantuvieron relaciones conflictivas con el propio virrey ${ }^{16}$. Sin embargo, ese apoyo al régimen pudo significar pragmáticamente un acomodo político de Larriva para mantener sus intereses particulares. Esta idea cobraría mayor sustento a partir del comportamiento del clérigo desde la llegada de San Martín a Lima en 1821. En esta nueva coyuntura quiso probar, obstinadamente, como seguro intentaron muchos

Lima durante las Cortes de Cádiz, 1810-1814”, (tesis Lic. Historia-UNMSM, 2008), 146-147; y, Víctor Peralta Ruiz, En defensa de la autoridad. Política y cultura bajo el gobierno del virrey Abascal. Perú, 1806-1816 (Madrid: CSIC-Instituto de Historia), 47.

12 Larriva también auspició los periódicos El Argos Constitucional, El Anti-Argos, El Cometa y escribió algunos artículos en El Verdadero Peruano. Véase: Daniel Morán, Reformistas, fidelistas y contrarrevolucionarios, 89 .

13 Daniel Morán, “¿Educando a los súbditos? Modernidad y tradición en una época revolucionaria. El Investigador [del Perú] (1813-1814)”, Revista Historia Crítica 41 (2010): 112-114.

14 Raúl Porras Barrenechea, Los ideólogos de la emancipación (Lima: Editorial Milla Batres, 1974), 131.

15 José Joaquín de Larriva, Arenga que en presencia del Excmo. Señor Virrey Don José Fernando Abascal, pronunció por la Real Universidad de San Marcos en el besamanos del 27 de diciembre de 1812, el D. D. José Joaquín de Larriva (Lima: Imprenta de los huérfanos, por D. Bernandino Ruiz, 1813), 35-40.

16 Daniel Morán, Reformistas, fidelistas y contrarrevolucionarios, 83-85. 
otros, su decidida participación por la causa patriota. En 1822, pide a la Junta Eclesiástica de Purificación la aprobación de su labor activa por la independencia, presentando para ello tres testimonios de otros ilustres ciudadanos limeńos ${ }^{17}$. Estas evidencias a la vez que mostraron el patriotismo de Larriva advirtieron además su importante participación en la prensa y en la difusión de los papeles públicos de la capital. Por ejemplo, mientras Mariano Tramarria sostuvo: "en tiempo del Gobierno tirano español me traía a mi casa varios papeles impresos de Buenos Aires y Chile para que se los guardase [...] todo lo que participaba a los amigos y patriotas que se reunían en mi habitación", el marqués de Monterrico incidía, "es indudable el influjo que la lectura de estos papeles ha tenido para formar la opinión pública y cimentar la incontrastable fuerza moral en los pueblos".

Esta compleja trayectoria política de Larriva es importante indicarla para comprender la figura de Fernando López Aldana y su participación en la prensa de Lima, la relación conflictiva que tuvo con el régimen de Abascal y su vinculación política con los revolucionarios rioplatenses ${ }^{18}$. López $\mathrm{Al}$ dana, abogado bogotano, puede representar un escritor público de enlace entre la prensa limeńa y la del Río de la Plata. En 1811 publicó El Diario Secreto de Lima, manuscrito clandestino, calificado de sedicioso y perturbador de la tranquilidad social y en abierta oposición al despotismo del virrey Abascal. Esta constatación se hace más patente cuando en el mismo Diario insiste en persuadir al propio virrey en entregar el poder al pueblo esperando que con esta actitud la autoridad colonial pueda salvarse de la censura universal ${ }^{19}$. Además, los intereses que López Aldana buscó con la difusión de su Diario Secreto no estuvieron limitados a llegar únicamente a un reducido grupo social del virreinato del Perú. Se puede observar en los diversos números del Diario una constante inquietud en servir de medio de ilustración de las clases más ínfimas, explotadas y numerosas de la

17 Archivo Arzobispal de Lima, Junta Eclesiástica de Purificación, "Documentos relacionados al expediente de purificación de don José Joaquín Larriva”, 1822. Recuérdese que estos tres ilustres limeños eran Don Mariano Tramarria, el señor marqués de Monterrico y el doctor Manuel Concha, los cuales testificaron a favor del patriotismo de Larriva.

18 Víctor Peralta Ruiz, La independencia y la cultura política peruana, 1808-1821 (Lima: IEP- Fundación M. J. Bustamante De la Fuente, 2010), 204-205; Joelle Chassin, "Lima, sus elites y la opinión", 247-248; y, Ascensión Martínez Riaza, La prensa doctrinal en la independencia, 31.

El Diario Secreto de Lima. № 3, miércoles 6 de febrero de 1811. 
sociedad colonial. El objetivo era destruir la ignorancia y el despotismo del antiguo régimen e infundir el amor por la libertad abriendo "los ojos a los peruanos". Para cumplir estos propósitos, y ante la mirada amenazante y censuradora de Abascal, López Aldana consiguió que su Diario Secreto se imprimiera en Buenos Aires y se publicara en ese mismo año en las páginas de la Gaceta, periódico oficial de la revolución rioplatense.

Si analizamos El Diario Secreto podemos percatarnos que se propició la unión de los peruanos con los revolucionarios porteños y el apoyo clave a los insurgentes de Santa Fe, Caracas, Chile, Quito e incluso de México ${ }^{20}$, sin embargo, esta inclinación de López Aldana más que buscar la ruptura definitiva con España, evidenció su apego y preferencia por una autonomía política de los americanos. Entonces, el sentido crítico de su discurso político debe entenderse en esta búsqueda de autonomía antes que de ruptura, más aún si su autor se encontraba en pleno centro del poder colonial y sin el amparo de la libertad de imprenta ${ }^{21}$.

Este comportamiento más político de López Aldana en la prensa se puede percibir cuando publica El Satélite del Peruano en 1812. Este periódico a pesar de su "moderación" fue calificado por el virrey, exageradamente, como el más incendiario y subversivo que había salido de las prensas de la capital ${ }^{22}$. Este calificativo puede explicarse por el pedido que hace el director El Satélite para la destitución del virrey del poder, no obstante, esta solicitud no advertía de ninguna manera la búsqueda de la ruptura con España. Por ello, López Aldana, desde El Satélite, se aferró a la propuesta de la ilustración del pueblo antes de volver a sostener una asociación declarada con los rebeldes porteños.

¿Cómo entender la participación de este hombre en la prensa limeña y la vinculación conflictiva con el poder colonial y su apoyo a los movimientos rebeldes americanos? López Aldana si bien no formó parte de la prensa adicta al virrey, sí representaría a un sector liberal del grupo criollo de Lima que buscaba aprovechar la nueva situación política inaugurada por

20 El Diario Secreto de Lima. $N^{\circ}$ 1, viernes 1 de febrero de 1811.

21 Daniel Morán, Batallas por la legitimidad.

22 Memoria de Gobierno de José Fernando de Abascal y Sousa (Sevilla, tomo I, 1944), 435. 
las Cortes de Cádiz y sus reformas, para acrecentar su poder y sus influencias políticas. Así, su discurso en la prensa "disidente" debe analizarse como una forma política y pública con la cual deseaba mantener sus intereses y abrirse un camino hacia una mayor participación política del poder del Estado. Además, ese discurso tiene que calibrar el contexto de las guerras de independencia y su incidencia en la configuración ideológica y política de los diversos grupos sociales inmersos en ella. Entonces, su apoyo a los revolucionarios rioplatenses tiene que inscribirse en esa tendencia de análisis e interpretación histórica.

Obviamente, este estudio de López Aldana sería incompleto si no comprendemos su participación en el régimen de San Martín que prueba claramente esas conexiones con los rebeldes de Buenos Aires. El autor de El Diario Secreto de Lima y El Satélite del Peruano en el contexto de Cádiz, se convertiría en un acérrimo patriota en el protectorado. En aquella coyuntura publicaría en Los Andes Libres de 1821 y en El Correo Mercantil, Político y Literario de 1821-1824. Como ha indicado Ascensión Martínez Riaza $^{23}$, y a partir de la lectura de las páginas de estos periódicos, podemos percibir la pluma y la tinta de este escritor público que en un nuevo contexto de guerra de opinión creyó conveniente, otra vez, utilizar políticamente a la prensa. Si bien en ambos periódicos encontramos algunos artículos con sus iniciales, buena parte de la estructura y los discursos políticos publicados llevan su impronta ideológica.

De esta coyuntura periodística de las guerras de independencia tenemos también a Hipólito Unanue, José Paredes, Félix Devoti, José Faustino Sánchez Carrión y Bernardo de Monteagudo. Unanue es un escritor público que participó en las tres etapas de la prensa peruana: en la coyuntura de $E l$ Mercurio Peruano, en el interregno gaditano con El Verdadero Peruano y El Peruano Liberal, y además entre 1821 y 1824 como en Trujillo con El Nuevo Día del Perú. En palabras de Unanue: "Una educación viciosa y servil debe ceder a las ideas del hombre libre: debe el pueblo abrir los ojos sobre sus intereses verdaderos, y debe arrancarse la máscara a los intrigantes, si queremos que el orden se establezca, y que reviva la opinión pública

23 Ascensión Martínez Riaza, La prensa doctrinal en la independencia, 81-84. 
amortiguada" ${ }^{24}$. José Paredes conocido editor de La Gaceta del Gobierno de Lima entre 1810-1819 y de las Guías de Forasteros, tuvo en 1821-1822 un desempeño importante en la prensa gracias a sus aportes en El Pacificador del Perú y El Sol del Perú y como miembro de la Sociedad Patriótica ${ }^{25}$. Por ejemplo, en un artículo publicado en El Sol del Perú en 1822 advirtió sobre las jugadas de toros en Lima: "es de absoluta necesidad la abolición de una costumbre que, sobre ser contraria a la humanidad, destructora de la moral, de la economía y del orden, y por lo mismo infamante al pueblo que la conserve, es actualmente incompatible con nuestras urgencias públicas" 26 . Esas urgencias fueron compartidas por otro escritor público sumamente importante desde la coyuntura de Cádiz hasta el protectorado de San Martín: Félix Devoti. Él mantuvo contacto con los miembros de la Sociedad Amantes del País de El Mercurio Peruano, escribió en La Minerva Peruana en plena crisis española, en los años de Cádiz aparece en El Verdadero Peruano, El Argos Constitucional y El Investigador del Perú, y, finalmente, en el protectorado se hace cargo de múltiples escritos en $\mathrm{La}$ Gaceta del Gobierno de Lima Independiente, Los Andes Libres, El Correo Mercantil, Político y Literario, y además del periódico de la Sociedad Patriótica El Sol del Perú ${ }^{27}$. En las páginas de Los Andes Libres de 1821 Devoti en un extenso artículo sobre la educación afirmó: "es necesaria una educación patriótica para que exista una patria [...] inspiremos al pueblo aquella permanente energía que ha de ser siempre el terror de sus enemigos [...] la educación [...] es la base de la felicidad de los pueblos"28.

Precisamente, la definición de la forma de gobierno que debía instalarse en el Perú fue un tema de discusión política durante el protectorado. Las páginas de la prensa y la activa participación de los escritores públicos se hicieron presentes en ella. La Sociedad Patriótica con El Sol del Perú y las figuras que hemos mencionado como Devoti, Paredes, Moreno, entre otros, enfrentaron los argumentos de Bernardo Monteagudo plasmados en El Pacificador del Perú y sus primigenias ideas en El Censor de la Revolu-

24 Prospecto del Nuevo Día del Perú, Trujillo, julio de 1824.

25 Ascensión Martínez Riaza, La prensa doctrinal en la independencia, 77-78.

26 El Sol del Perú, N² 2, Lima, jueves 21 de marzo de 1822.

27 Daniel Morán y Wilder Calderón, La revolución del impreso. La prensa y el lenguaje político en la independencia (Lima: Fondo Editorial de la Universidad Peruana Simón Bolívar, 2014); y Ascensión Martínez Riaza, La prensa doctrinal en la independencia, 74-76.

28 Los Andes Libres, $N^{\circ} 11$, Lima, viernes 26 de octubre de 1821. 
ción en Chile y Mártir o Libre en Buenos Aires. Además, desde 1821-1822 a través de La Abeja Republicana, El Correo Mercantil, Político y Literario y El Tribuno de la República Peruana, José Faustino Sánchez Carrión haría frente a los argumentos de Monteagudo. Para este último, partidario de una monarquía constitucional, "Hablaremos de la opinión, de ese gran conductor eléctrico, que con una rapidez igual a aquella con que se propaga el fluido que produce los más portentosos fenómenos de la naturaleza, ha difundido el espíritu de Libertad, en toda la extensión del Perú"29. Por su parte, Sánchez Carrión, férreo defensor del republicanismo en el Perú, criticó las ideas de Monteagudo señalando la "Inadaptabilidad del gobierno monárquico al Estado libre del Perú”, publicado en las páginas de La Abeja Republicana en agosto de 1822. En palabras de Sánchez Carrión: "yo quisiera, que el gobierno del Perú fuese una misma cosa que la sociedad peruana, así como un vaso esférico es lo mismo que un vaso con figura esférica" ${ }^{30}$. Las diferencias ideológicas entre Monteagudo y Sánchez Carrión determinaron una discusión política en la prensa en 1822, incluso después de su destitución y el final del protectorado. Estos escritores públicos convertidos en personajes políticos de los gobiernos instalados a partir de la independencia nos muestran esta relación entre la prensa, el discurso político y el poder del Estado. Más aún, José Faustino Sánchez Carrión, defensor del republicanismo en el Perú, con el apoyo de Guillermo del Río siguió publicando sus ideas en El Correo Mercantil, Político y Literario (1821-1824) y El Tribuno de la Republica Peruana (1822).

Sin embargo, debemos agregar además la posición realista y fidelista en la prensa de esta coyuntura con la difusión del Triunfo de la Nación (1821) y El Depositario (1821-1825). En estos papeles públicos destacaron los escritos y las editoriales de Guillermo del Río y Gaspar Rico y Angulo, ambos personajes que estuvieron presentes en la revolución del impreso en el contexto de las Cortes de Cádiz en el Perú. En otras palabras, personajes públicos clave en todo el proceso de las guerras de independencia y el desarrollo de la opinión pública en Lima ${ }^{31}$.

29 El Pacificador del Perú, № 7, Lima-Barranca, 10 de junio de 1821.

30 La Abeja Republicana, $N^{\circ}$ 4, Lima, jueves 15 de agosto de 1822, t. 1.

31 Daniel Morán y María Aguirre, Prensa política y educación popular en la independencia de América Latina (Lima: Fondo Editorial de la Universidad de Ciencias y Humanidades, 2015); y Ascensión 
Un tema importante en la publicación de la prensa y sus múltiples redes de comunicación estuvo vinculado a la presencia de sociedades auspiciadoras de los papeles públicos, los cafés y las tertulias en donde estos escritores públicos debatieron sus ideas acaloradamente. Por ejemplo, la Sociedad Amantes del País produjo El Mercurio Peruano entre 1791-1795, La Tertulia del Campo difundió El Peruano en 1811-1812 y Fernando López Aldana señaló que la Sociedad Filantrópica asistía a El Satélite del Peruano en 1812. Por su parte, una Junta de Literatos, incluido el reconocido Hipólito Unanue, solventados por Abascal producía El Verdadero Peruano entre 1812-1813, en este último año El Argos Constitucional y El Peruano Liberal eran auspiciados por el Ayuntamiento Constitucional de Lima, mientras que El Investigador y La Gaceta de Lima eran favorecidos por el régimen del virrey. Entre 1815 y 1820, La Gaceta de Lima monopolizó los discursos políticos en el Perú y, efectivamente, las autoridades españolas produjeron y solventaron a la gaceta oficial. Fue en 1821 con la llegada de la expedición libertadora de San Martín y la participación de Monteagudo que advertimos la creación de la Sociedad Patriótica en el Perú, incluso, Jorge Luis Castro Olivas, incide en la presencia de la Logia Lautaro en Lima, pero de una logia debilitada, para nada comparable con la de Buenos Aires y Santiago de Chile, logia donde San Martín fue su líder ${ }^{32}$. Durante el protectorado, San Martín y Monteagudo sostuvieron El Pacificador del Perú, El Americano y Los Andes Libres en 1821 con un objetivo político claro: la consolidación de la revolución y el establecimiento de la independencia. Igualmente, fueron los promotores de la Sociedad Patriótica de Lima auspiciando su órgano oficial El Sol del Perú en 1822 y, además, La Gaceta del Gobierno de Lima Independiente. En el prospecto de El Sol del Perú se hace evidente el papel de la Sociedad Patriótica, la ilustración y la prensa:

"El gobierno penetrado de tan sublimes ideas no perdona medios para proteger la ilustración de estos pueblos, y corregir el fatal abandono en que los ha dejado la desidia española. Todo se resiente de su benéfico influjo; y serán otros tantos monumentos de

Martínez Riaza, La prensa doctrinal en la independencia, 42-44.

32 Jorge Luis Castro Olivas, "Sociedades secretas y masonería en el proceso de emancipación peruano: la Logia Lautaro en el Perú”, (tesis Mg. Historia-UNMSM, 2009). 
su filantropía y su celo la magnífica Biblioteca que se construye, y la reforma tan necesaria del teatro, de esta escuela de la moral pública, a donde el hombre riéndose de sí mismo, corrige sus costumbres y vicios. Bajo tan prósperos auspicios se ba instalado una sociedad patriótica y literaria, presidida por el benemérito Señor Ministro de Estado, bien conocido por su delicado gusto y amor a las letras; y los cuarenta individuos que la componen esperan con sus tareas merecer la confianza pública y del gobierno. La sociedad se ha dividido en cuatro secciones, en las que se tratará con distinción sobre los asuntos más interesantes de agricultura, política, literatura y ciencia; que reunidos en cada cuatrimestre darán al público el fruto de sus trabajos [...] Entretanto, saldrá el jueves de cada semana un periódico con el título: EL SOL DEL PERÚ. En él se tratará de amenizar con la variedad las materias de que se trate" 33 .

En contraste con los proyectos monárquicos constitucionales y en oposición a las directrices de la Sociedad Patriótica se publicaron los periódicos republicanos La Abeja Republicana, El Tribuno de la República Peruana y, también, El Correo Mercantil, Político y Literario, donde confluyeron diversas tendencias políticas del pensamiento peruano y escritores públicos como Fernando López Aldana, José Joaquín de Larriva, Félix Devoti y el propio José Faustino Sánchez Carrión ${ }^{34}$. Efectivamente, hemos apreciado la participación clave de los escritores públicos de Lima en la prensa en los tiempos de la independencia y su vinculación al poder y la legitimidad de la autoridad política.

\section{Los escritores públicos de la Revolución en Buenos Aires}

En el caso de Buenos Aires los escritores públicos, gaceteros y panfletistas formaron parte en un primer momento de lo que se ha denominado los jacobinos rioplatenses en la prensa de mayo. ${ }^{35}$ En ese sentido, en marzo de 1810, a pocos días de la revolución de mayo, Manuel Belgrano uno de

33 Prospecto El Sol del Perú, № 1, Lima, jueves 14 de marzo de 1822.

34 Daniel Morán y Wilder Calderón, La revolución del impreso, 141-178; y Ascensión Martínez Riaza, La prensa doctrinal en la independencia, 45-50.

35 Silvana Carozzi, Las filosofías de la revolución. 
estos pensadores y hombre de armas, publicaba El Correo de Comercio (1810-1811), en donde plasmaba ideas de índole económica y circunscrita además en la educación de los pueblos, sin que esto significara el total abandono de los asuntos políticos ${ }^{36}$. Tal vez está inclinación por los “asuntos periféricos" y alejados de lo político se debiera, al menos hasta los prolegómenos de los acontecimientos de mayo, a la protección que tuvo del régimen colonial ${ }^{37}$. Sin embargo, en dicho periódico podemos advertir algunos artículos que soterradamente hacían una crítica al gobierno colonial haciéndonos pensar en la contribución de la pluma de Belgrano a esta guerra de opinión ante los inminentes acontecimientos de la revolución y después de ella ${ }^{38}$. Por ejemplo, la afirmación que expresara sobre la miserable condición de la educación popular en el Río de la Plata y, también, la propuesta claramente persuasiva, casi una imposición, de encomendar a los religiosos a esa empresa de instrucción de los pueblos, ofrecen algunas evidencias de sus críticas subrepticias al régimen español. ${ }^{39}$ No obstante, Belgrano publicaría, en El Correo de Comercio, a menos de una semana del inicio de los acontecimientos de mayo, un testimonio importante que daba cuenta de las "causas de la destrucción o de la conservación y engrandecimiento de las naciones", imputando como causa principal de los desastres de la nación a la constante desunión de su habitantes mientras que creía que la unión era el emblema de su engrandecimiento ${ }^{40}$. Igualmente, después de tres meses de los sucesos revolucionarios y como vocal de la Primera Junta de Gobierno, Belgrano en un artículo sobre la libertad de imprenta concluía que dicha libertad era la principal base de la educación pública, de la libertad civil y del buen gobierno en abierto rechazo al despotismo y a la tiranía ${ }^{41}$.

36 Armando Piñeiro, El periodismo porteño en la época de la independencia (Buenos Aires: ANP, 2008), 21-26; y, Óscar Beltrán, Historia del periodismo argentino (Buenos Aires: Editorial, 1943), 30-37.

37 Silvana Carozzi, Las filosofías de la revolución, 174-175.

38 Juan Carlos Garavaglia, Construir el estado, inventar la nación. El Río de la Plata, siglos XVIII-XIX (Buenos Aires: Prometeo, 2007), 234; y, Armando Piñeiro, El periodismo porteńo, 33-35.

3439 El Correo de Comercio. № 3 y 4, Buenos Aires, sábado 17 y 24 de marzo de 1810, respectivamente. 40 El Correo de Comercio. № 12, Buenos Aires, sábado 19 de mayo de 1810.

41 El Correo de Comercio, № 24, Buenos Aires, sábado 11 de agosto de 1810. Véase: Armando Piñeiro, El periodismo porteño, 37-38; y, Silvana Carozzi, Las filosofías de la revolución, 181-182. 
Esta primera experiencia directa de Belgrano en la prensa no quedaría allí ${ }^{42}$. Aunque después de El Correo de Comercio no animara otro periódico, sí lo encontramos presente en muchas de las páginas de La Gaceta de Buenos Aires, informando al gobierno revolucionario sobre sus acciones militares en el Paraguay, la banda oriental, Salta, Tucumán y el Alto Perú. Así, en 1814 en carta dirigida a San Martín le advertía sobre los problemas que pudiera encontrar en los pueblos del interior, sugiriéndole que "la guerra, allí, no solo ha de hacer usted con las armas, sino con la opinión” ${ }^{43}$.

Si con El Correo de Comercio apreciamos los primeros brotes de una guerra en donde los discursos son importantes para el establecimiento de la opinión, con la aparición en junio de 1810 de La Gaceta de Buenos Aires, vocero oficial del nuevo orden revolucionario, este argumento cobró mayor relevancia. La figura de su fundador y principal redactor Mariano Moreno fue fundamental en la labor pedagógica del nuevo gobierno. Moreno como secretario de la junta tuvo una íntima participación política en los acontecimientos de la revolución ${ }^{44}$. Casi la totalidad de los números de La Gaceta fueron seleccionados por Moreno y las editoriales corrieron por su cuenta hasta diciembre de 1810 cuando cede su puesto de redactor al Deán Gregorio Funes ${ }^{45}$.

Mariano Moreno es considerado el más radical de los hombres de mayo, fue el encargado del departamento de gobierno y guerra, de su pluma salieron sendos discursos para la educación de los pueblos, la formación de opi-

42 Por ejemplo, es evidente la influencia de Manuel Belgrano en los dos primeros periódicos del Río de la Plata, El Telégrafo Mercantil (1801-1802) y El Semanario de Agricultura (1804-1807), propiciando el apoyo del Consulado de Buenos Aires y, además, publicando algunos artículos en las páginas de esos diarios. Véase: Óscar Beltrán, Historia del periodismo argentino, 28.

43 Ricardo Tito (comp.), El pensamiento de los hombres de Mayo (Buenos Aires: Editorial Ateneo, 2009), 227.

44 Noemí Goldman (ed.), Lenguaje y revolución: Conceptos políticos clave en el Río de la Plata, 17801850 (Buenos Aires: Prometeo, 2008), 99-100; y, Silvana Carozzi, Las filosofías de la revolución, 64-65.

45 Graciana Vázquez, Revolución y discurso. Un portavoz para la integración hispanoamericana: Bernardo Monteagudo (1809-1825) (Buenos Aires: La isla de la luna, 2006), 67; Óscar Beltrán, Historia del periodismo argentino, 44-52. El Deán Gregorio Funes solamente se hizo cargo de la Gaceta algunos meses de 1811 destacándose por su pluma elegante y disuasiva. Debe subrayarse su discurso sobre la libertad de prensa y el reglamento que devino de él para entender tanto los límites como las ventajas de esa libertad ahora reglamentada por el poder político. Además, es importante resaltar su papel en el púlpito a través de sus panfletos, sermones y su oratoria patriótica en la década revolucionaria. 
nión a favor del gobierno y las instrucciones para las expediciones militares que buscaban acabar con la opresión de las demás regiones en poder de las armas realistas. En sus discursos publicados en La Gaceta de Buenos Aires, en noviembre y diciembre de 1810, Moreno esbozó sus principales planteamientos ideológicos en torno "a la soberanía 'indivisible, e inalienable' como fundamento de la voluntad general”, buscando, además, la reunión de un congreso de los pueblos que debía elegir gobernantes, emancipar al Río de la Plata de España, pero, principalmente, fijar una Constitución y una forma de gobierno.

Precisamente, Moreno concibió a la prensa como un medio fundamental para afianzar el espíritu público y el respeto a la autoridad política y, en ese fin, subrayó su honda preocupación por la libertad de imprenta, afirmando que se dé:

“acceso a la verdad, y a la introducción de las luces [...] no se reprima la inocente libertad de pensar [...] si se oponen restricciones al discurso, vegetará el espíritu [...] y el error, la mentira [...], el fanatismo y el embrutecimiento, harán la divisa de los pueblos, y causaran para siempre su abatimiento, su ruina y su miseria" ${ }^{46}$.

Es evidente que la presencia de Manuel Belgrano y Mariano Moreno en la prensa porteńa, en los acontecimientos políticos de la revolución de mayo y su participación en el nuevo gobierno rioplatense prueban estas relaciones entre la esfera del poder y la prensa política.

En esa perspectiva, los escritores públicos también generaron discusiones y debates políticos en las páginas de la prensa. En el Buenos Aires revolucionario tenemos por ejemplo el surgimiento de una prensa particular que rompe la unanimidad de La Gaceta de Buenos Aires en 1812: apareció El Censor de Vicente Pazos Silva ${ }^{47}$ y Mártir o Libre de Bernardo de Monteagudo. Incluso, Pazos y Monteagudo desde fines de 1811 habían entablado una polémica periodística en las páginas de La Gaceta. En este periódico y

46 La Gaceta de Buenos Aires, No3, jueves 21 de junio de 1810.

47 Pazos Silva volvería a publicar otro periódico en 1816 con el título de La Crónica Argentina. 
después en El Censor y Mártir, Pazos de tendencia moderada y de simpatías monárquicas debatió con Monteagudo inclinado más a la radicalidad y su apuesta por la independencia ${ }^{48}$.

Es indudable que de aquellos animadores de la prensa rioplatense la figura de Bernardo de Monteagudo es la que más ha atraído a la historiografía especializada ${ }^{49}$. Si desde La Gaceta venía insinuando su tendencia ideológica, con la publicación de Mártir o Libre e incluso de El Grito del Sud en ese mismo año, Monteagudo se convierte en el propulsor de la propuesta radical de la revolución que insiste en la independencia definitiva de la dominación española. En Mártir o Libre se percibe una pedagogía política que buscó la educación del ciudadano y la instalación de una nación independiente rechazando en forma rotunda toda insinuación monárquica, despótica y absolutista. Con El Grito del Sud se advierte la vinculación de la prensa y la Sociedad Patriótica de la cual Monteagudo fue presidente y el periódico el vocero directo de dicha institución. Esta sociedad representó en 1812 a un grupo de poder consolidado que a través de su periódico difundía la idea de la independencia y la redacción de la Constitución reafirmando su tendencia revolucionaria e influyendo en los acontecimientos políticos del gobierno en Buenos Aires ${ }^{50}$.

Recordemos que ha sido Bernardo de Monteagudo el escritor público y hombre de armas que ha recorrido toda la coyuntura revolucionaria y ha desarrollado una enorme influencia en la prensa y la esfera política de América del Sur. Monteagudo aparte de escribir en la prensa de mayo, redactó también en el Santiago de Chile patriota en 1820 El Censor de la Revolución, tiempo antes participó de otras publicaciones chilenas y, en 1821, publicó diversas editoriales en El Pacificador del Perú y como ministro del protectorado auspició las publicaciones del Americano, Los Andes

48 Graciana Vázquez, Revolución y discurso, 67-68; y, Eugenia Molina, El poder de la opinión pública, 223-224.

49 Graciana Vázquez, Revolución y discurso; Gustavo Montoya, La independencia del Perú y el fantasma de la revolución (Lima: IEP-IFEA, 2002); y, Carmen Mc Evoy, "De la comunidad retórica al Estado-Nación: Bernardo Monteagudo y los dilemas del republicanismo en "América del Sud", 1811-1822", en Convivencia y buen gobierno: nación, nacionalismo y democracia en América Latina, comps, José Nun y Alejandro Grimson (Buenos Aires: Edhasa, 2006).

50 Graciana Vázquez, Revolución y discurso, 69-71; y, Silvana Carozzi, Las filosofías de la revolución, 233-301. 
Libres, El Sol del Perú y La Gaceta del Gobierno de Lima Independiente ${ }^{51}$.

Por ejemplo, en El Censor de la Revolución de julio de 1820, Monteagudo escribió:

"No es solo la libertad del Perú y la independencia del nuevo mundo, no es solo la suerte de las generaciones venideras y la causa de las civilizaciones que es trascendental a toda la especie, no es solo el comercio de las naciones industriosas y la prosperidad de todos los hombres que quieren participar las ventajas de nuestros fecundos climas; es la justicia, es la tranquilidad de nuestras familias, es nuestras [misión] que se hallan pendientes de esta empresa decisiva" 52 .

Dicha empresa se estableció con la campaña hacia el Perú y en las páginas de El Pacificador del Perú en 1821 Monteagudo reafirmó:

"La América llegó en fin a adquirir el sentimiento de sus propias fuerzas: el imperio de la opinión se estableció rápidamente [...] los sucesos públicos avisaron que la revolución era general, que participaban de su espíritu, aún las mismas provincias que permanecían bajo el yugo; porque todo el pueblo que piensa en sus desgracias, y tiene cerca de sí un ejemplo de los medios que han empleado otros para evitarlas, ya está en revolución" ${ }^{33}$.

Por otro lado, entre 1815 y 1820 se publicaron diversos periódicos que mantuvieron relaciones con La Gaceta de Buenos Aires y los múltiples acontecimientos políticos de toda esa coyuntura revolucionaria. Los escritores públicos se ocuparon de estos ruidos políticos y las discusiones periodísticas se desarrollaron abiertamente. Un personaje central en la prensa de estos años fue Antonio José Valdés, quien publicó y redactó El Censor entre 1815 y 1817, y La Prensa Argentina de 1815 y $1816^{54}$. Valdés supo

51 Daniel Morán y María Aguirre, Prensa política y educación popular; y, Beatriz Bragoni, San Martín. De soldado del Rey a héroe de la nación (Buenos Aires: Editorial Sudamericana, 2010).

3852 El Censor de la Revolución, N ${ }^{\circ}$ 7, Santiago de Chile, 10 de julio de 1820.

53 El Pacificador del Perú, № 1, Lima-Huaura, 10 de abril de 1821.

54 Óscar Urquiza, La cultura de Buenos Aires a través de su prensa periódica, 1810-1820 (Buenos Aires, Eudeba 1972), 17-20. 
relacionar y problematizar los temas de índole político, militar, económico y cultural en sus publicaciones. Sin embargo, en todo este tiempo los discursos políticos contenidos en las páginas de la prensa dependieron del contexto de guerra y revolución desarrollado en Buenos Aires y en toda América. En palabras de El Censor: "Elevadas las provincias del Sud al rango de nación que aspiran obtener. Parece propio del Censor desempeñar su encargo de ilustrar a los pueblos en todos aquellos objetos que su nueva situación requiere" 55 . Más aún, el propio Valdés sostuvo en La Prensa Argentina de 1815: "cuando corro la imaginación por las revoluciones de América, y advierto su vasta superficie teñida de sangre, y sus habitantes lidiando contra la opresión española, no puedo menos de alabar la noble determinación de los americanos, abominar el bárbaro empeño de sus opresores" ${ }^{56}$. De estos periódicos fue El Censor el que mantuvo una periodicidad mayor, gracias a la labor de otro escritor público, conocido por iniciar la labor de la prensa en Santiago de Chile con La Aurora en 1812, como Camilo Henríquez quien se hizo cargo del periódico porteño a inicios de 1817 hasta febrero de 1819.

Igualmente, Pedro José Agrelo a través de las páginas de El Independiente entre 1816 y 1817, y El Abogado Nacional de octubre de 1818 y mayo de 1819, pudo difundir sus preceptos políticos vinculados a la realidad rioplatense y la independencia de América. Recordemos además a Vicente Pazos Silva que difundió El Censor de 1812 y luego se hizo cargo entre 1816 y 1817 de La Crónica Argentina. Finalmente, otro personaje público importante en la prensa de esta coyuntura fue el Deán Gregorio Funes desde la publicación de La Gaceta de Buenos Aires de 1811 y, junto al fray Cayetano Rodríguez, en El Redactor del Congreso Nacional entre mayo de 1816 y enero de $1820 .{ }^{57}$ En este punto se relacionan los discursos políticos contenidos en la prensa y la prédica religiosa así como los sermones, las cartas pastorales y la correspondencia pública y privada. Efectivamente, entre 1810 y 1820 , en Buenos Aires circulo un conjunto amplio de periódicos en donde diversos escritores públicos, hombres de armas y personajes políticos se manifestaron en esfera de la opinión pública y en el debate de los asuntos públicos.

55 El Censor, $\mathrm{N}^{\circ}$ 53, Buenos Aires, jueves 29 de agosto de 1816.

56 La Prensa Argentina, $\mathrm{N}^{\circ}$ 2, Buenos Aires, martes 19 de septiembre de 1815.

57 Óscar Urquiza, La cultura de Buenos Aires, 13-27; y, Eugenia Molina, El poder de la opinión pública. 


\section{Entre ReVolucionarios y contrarreVOlUCiOnarios. Prensa y escritores públicos en Santiago de Chile.}

"Si los papeles públicos son el barómetro con que se mide la ilustración de un país, debió haberse formado una idea muy poco ventajosa de la nuestra, cuando se vio, que trastornado el despotismo español, seguimos guardando el mismo silencio a que aquel nos condenaba" ${ }^{58}$, con estas palabras inició en julio de 1818 El Chileno, desde una perspectiva crítica, la justificación de su presencia en la escena periodística nacional y un breve pero interesante repaso de la historia del periodismo en Chile ${ }^{59}$.

El proceso revolucionario de mayo de 1810 en Buenos Aires repercutió en diversas partes de América, especialmente en Santiago de Chile, cuando en septiembre de 1810 se estableció por Cabildo abierto la junta de gobierno. A partir de este acontecimiento se inició todo un proceso revolucionario en donde la guerra y el poder de la opinión jugaron un papel fundamental. Así lo entendieron los nuevos revolucionarios e intentaron en Chile la adquisición de una imprenta propia, la cual pudieron conseguir en 1811 por intermediación de Mateo Arnaldo Hoevel y el apoyo, poco tiempo después, del nuevo gobierno de José Miguel Carrera ${ }^{60}$. En este contexto, apareció La Aurora de Chile en febrero de 1812 y el gobierno nombró a Camilo Henríquez como el escritor público central del primer periódico en Chile. Henríquez también se encargó del segundo periódico chileno, El Monitor Araucano, entre 1813 y 1814. La mayoría de editoriales y noticias principales de ambos periódicos revolucionarios fueron redactados por Camilo Henríquez. Este patriota y revolucionario creyó en la revolución y en la independencia de Chile y a través de las páginas de La Aurora y El Monitor buscó llevar adelante este ideal en aquel contexto de guerra y revolución ${ }^{61}$. En palabras de Henríquez y La Aurora:

58 Prospecto El Chileno, Santiago de Chile, miércoles 15 de julio de 1818.

59 Ángel Soto (ed.). Entre tintas y plumas. Historia de la prensa chilena del siglo XIX (Santiago: Universidad de los Andes, 2004).

60 Carlos Pérez Guerra, La importancia de los periódicos de la Patria Vieja para el movimiento revolucionario nacional. El aporte de los escritos de Camilo Henríquez y Antonio José Irisarri (tesis Lic. Historia, Universidad de Chile, 2005); y, Antonia Rebollero, "La cultura", en Chile. Crisis imperial e independencia, 1808-1830, coord., Ricardo Couyoumdjian, Colección América Latina en la Historia Contemporánea, t. 1 (Madrid: Fundación Mapfre-Editorial Taurus, 2010), 247.

61 Alejandro San Francisco, "La vida política", en Chile. Crisis imperial e independencia, 1808-1830, 
"Tal es el execrable lenguaje de los opresores de la libertad del género humano: a su vista son insurgentes y rebeldes los pueblos generosos que combaten por sus derechos. Esta nota se ha repetido con frecuencia en todos los papeles que se han publicado en la época presente; pero a pesar de ellos, de los oráculos de la religión y de la eterna justicia, los derechos de los pueblos son vanas ilusiones a los ojos de los ambiciosos, de los fatuos, de los indolentes, de los egoístas. No advierten estos últimos que todos los particulares son envueltos en la desgracia general; que el vencedor ha de insultar a su cobardía, que ha de despreciarlos, después de que sirvan a sus talentos y que ha de vivir su descendencia en miseria y oprobio eterno" ${ }^{62}$.

El lenguaje de insurgentes y rebeldes y el significado que el editor le atribuyó al concepto de libertad estuvo vinculado a los acontecimientos y los intereses de los tiempos revolucionarios y al itinerario hacia la independencia nacional. Su percepción la dejó bien clara en El Monitor Araucano de 1813:

"La libertad se conquista con el valor o la fortaleza. Esta es la principal virtud de las repúblicas en sus varios estados, en sus principios, en sus agitaciones, y en la profunda paz. Pero no todos los ciudadanos deben manifestar el valor de un mismo modo. El magistrado que hace triunfar la ley, sea haciendo frente y destruyendo a los malvados, a los perturbadores de la quietud y del orden, a los complotados contra la libertad y seguridad del pueblo, paga a la patria el tributo del valor y de la magnanimidad, como el soldado que avanza bajo el fuego enemigo. Por la misma razón el público que sacrifica su opinión y sus sentimientos al terror, es tan cobarde como el militar, que en el combate arroja las armas y huye. El funcionario que por adulación, o por interés compromete los derechos populares, es tan perverso y vil como el militar que se dejase corromper por el dinero del enemigo" ${ }^{63}$.

coord., Ricardo Couyoumdjian, Colección América Latina en la Historia Contemporánea, t. 1 (Madrid: Fundación Mapfre-Editorial Taurus, 2010), 47-48; y, Carlos Pérez Guerra. La importancia de los períodicos.

62 La Aurora de Chile, $\mathrm{N}^{\circ}$ 9, Santiago, jueves 9 de abril de 1812.

63 El Monitor Araucano, $\mathrm{N}^{\circ}$ 1, Santiago de Chile, jueves 2 de diciembre de 1813., t. 2. 
Camilo Henríquez con estos argumentos se convirtió en el principal escritor público que a través de las páginas de la prensa hacía frente a la opinión pública realista y contrarrevolucionaria. A pesar de la dependencia de Henríquez con el gobierno pudo difundir sus preceptos políticos y su ideología patriota en Santiago de Chile ${ }^{64}$. A través de La Aurora de Chile y El Monitor Araucano pudo encender el debate político y polemizar con las fuerzas realistas y aportar en la politización de la población. Es indudable que ambos periódicos circularon por Santiago de Chile y diversas provincias y regiones de Chile además de su propagación por Buenos Aires, el Alto Perú, y el propio virreinato peruano ${ }^{65}$.

En esta coyuntura surgió también El Semanario Republicano en agosto de 1813 y su publicación estuvo en manos de Antonio José Irisarri. Este escritor público más independiente del gobierno pudo manifestar una posición abiertamente más sediciosa ${ }^{66}$. En argumentos de El Chileno de 1818:

"El Semanario Republicano fue el único fruto del reglamento de la imprenta libre" y "duró hasta que se cansó de escribir el que dictaba sus papeles, y haciendo justicia al autor debemos confesar, que no tenía miedo para manifestar sus opiniones pues desaprobaba y condenaba las operaciones de los hombres más temibles en aquella época" ${ }^{67}$.

Incluso, para el propio Semanario Republicano la independencia era una necesidad irreversible:

"Por donde quiera que se mire nuestra situación, no presenta más remedio que la absoluta independencia, procurada por los medios que nos dicte la razón y la política [...] la constancia sabrá hacer que pasemos por sobre los reveses de la suerte y las contingencias de la guerra inevitable [...] el valor nos hará conocer que

64 Prospecto El Chileno, Santiago de Chile, miércoles 15 de julio de 1818.

4265 Daniel Morán y María Aguirre, Prensa política y educación popular, 91-94; y, Antonia Rebollero, "La cultura”, 247-248.

66 Alejandro San Francisco, "La vida política", 48-49.

67 Prospecto El Chileno, Santiago de Chile, miércoles 15 de julio de 1818. 
nada aventuramos con la independencia, porque bastante mérito hemos dado ya para ser reputados por rebeldes; y poniendo toda nuestra seguridad en la suerte de las armas, llevaremos la victoria dependiente de nuestras hazańas [...] solo la independencia es capaz de ponernos a cubierto de las dobles cadenas que nos amenazan, y solo podemos empezar a contar los días de nuestra felicidad, desde aquel en que rompamos los funestos lazos que nos atan al despotismo español"68.

Antonio José Irisarri postuló una guerra e independencia inevitable en 1813 en Santiago de Chile como parte de la lucha revolucionaria americana. Para este escritor público patriota los principales temas del debate político se circunscribían a la libertad, los derechos del ciudadano, el cumplimiento de la ley, la Constitución y las diversas formas de gobierno con que podía contar una sociedad en un contexto realmente problemático y revolucionario ${ }^{69}$. Efectivamente, Irisarri fue más categórico que Camilo Henríquez en los diversos números de El Semanario Republicano. Por ejemplo, en septiembre de 1813 señaló: "Estos documentos que nos presenta la experiencia de los siglos nos hacen ver, que las Repúblicas solo pueden florecer por las virtudes de los Ciudadanos; y que es el mayor error, pretender el establecimiento de un Gobierno republicano en un pueblo vicioso y corrompido" ${ }^{70}$. Fue por este lenguaje crítico y de oposición, y las conmociones públicas que sus escritos ocasionaron que dejó de dirigir el periódico en octubre de 1813, pasando la dirección de El Semanario a Camilo Henríquez hasta febrero de 1814 . Esta primera experiencia de la prensa de Chile en la denominada Patria Vieja tuvo entonces en la pluma, el papel y las ideas de Camilo Henríquez y Antonio José Irisarri a sus más altos promotores y escritores públicos, los cuales a su manera y en la medida de sus posibilidades aportaron en el desarrollo del ciclo revolucionario y la consecución de la independencia.

La reconquista realista del general Osorio con el triunfo español en Ranca-

68 El Semanario Republicano, № 5, Santiago de Chile, sábado 4 de septiembre de 1813.

69 Carlos Pérez Guerra, La importancia de los periódicos, 49-65.

70 El Semanario Republicano, № 8, Santiago de Chile, sábado 25 de septiembre de 1813. 
gua en octubre de 1814 marcó el monopolio de la prensa oficial y la unidireccionalidad de los discursos políticos en Chile. Viva El Rey. La Gaceta del Gobierno de Chile copó los escritos públicos centrales entre 1814 y 1817, resaltando las ideas monárquicas y reproduciendo las noticias, editoriales y argumentos de La Gaceta de Lima. Es indiscutible que el manejo de la gaceta oficial estuvo en correspondencia con los intereses de las armas del rey y el sofocamiento de los movimientos rebeldes de América ${ }^{71}$. En el discurso de La Gaceta:

"Espíritus sublimes, hombres ilustrados, y juiciosos; el Gobierno os excita a empelar dignamente vuestras luces ayudándole con sabias producciones a ilustrar a los pueblos, y disipar la espesa niebla que en ellos ha esparcido la obscura Aurora de Chile, el falaz Monitor Araucano, el sedicioso Semanario Republicano, y demás papeles que hasta ahora habían afeado nuestra Imprenta, y que serán eternamente proscriptos" 72 .

Fueron los tiempos de la contrarrevolución en la guerra de la opinión pública en Chile y el fortalecimiento de una línea editorial monolítica que se rompería solamente con los triunfos de los patriotas en las batallas de Chacabuco en 1817 y Maipú en 1818.

En este nuevo contexto, La Gaceta oficial cambiaría de nombre y de intereses: llevó el título de Viva la Patria. La Gaceta del Supremo Gobierno de Chile, y, aquella misma coyuntura originó una diversidad de papeles públicos como El Argos de Chile, El Chileno, El Telégrafo, El Duende de Santiago, El Sol de Chile, El Censor de la Revolución, entre otros ${ }^{73}$. Precisamente, en este último periódico publicado en 1820, volvería a cobrar protagonismo otro escritor público y hombre de armas clave en el ciclo revolucionario: Bernardo de Monteagudo. Conocíamos sus ideas impresas en La Gaceta de Buenos Aires, Mártir o Libre y El Grito de Sud, y ahora en la dirección de El Censor de la Revolución volvió a difundir sus preceptos

73 Prospecto El Chileno, Santiago de Chile, miércoles 15 de julio de 1818. 
políticos y la necesidad de la independencia de América ${ }^{74}$. La principal preocupación de Monteagudo, en las páginas de El Censor de la Revolución, fue la consolidación de la independencia de Chile y, por ende, la materialización de la Campaña hacia el Perú con el objetivo de terminar con el poder realista en América:

"El interés de toda la América lo exige, los pueblos del Perú la desean con ansia, la existencia de Chile depende de ella, y la tranquilidad de las provincias del Rio de la Plata acaso resultará de su buen éxito. El Gobierno ha ofrecido mucho tiempo ha el efectuarla, y sus promesas han sido tan repetidas como estériles: hemos tenido tiempo sobrado para leer en los papeles de Europa los ardientes encomios que los amigos de la libertad han hecho a esta gloriosa empresa, y no hemos podido prescindir de un sentimiento de pena y de rubor al ver que no los merecíamos [...] algunos tienen la confianza de asegurar que no tardará el día en que los vencedores del Maipú vean y venzan a los opresores del Perú’75.

Como hemos advertido Monteagudo es el escritor público, hombre de armas y político clave que recorrió todo el ciclo revolucionario y mantuvo relaciones con los poderes del Estado y en todas sus intervenciones auspició y publicó periódicos que influyeron en el escenario político y cultural tanto de Buenos Aires como de Santiago de Chile y, especialmente, el Perú. La figura de Bernardo de Monteagudo podría sintetizar el itinerario ideológico y político de los escritores públicos y su presencia en la prensa revolucionaria en América del Sur.

\section{CONCLUSIONES: LOS ESCRITORES PÚBLICOS ENTRE DOS FUEGOS}

Después de todo este recorrido por la prensa y el papel que los escritores públicos cumplieron en ella, es evidente que su vinculación con el poder político resultó fundamental. Pero para que este objetivo se hiciera efectivo

74 Eugenia Molina, El poder de la opinión pública, Silvana Carozzi, Las filosofías de la revolución, y, Daniel Morán, Batallas por la legitimidad.

75 El Censor de la Revolución, N 1, Santiago de Chile, 20 de abril de 1820. 
fue imprescindible que estos hombres de letras se vincularan con otros escritores e intercambiaran informaciones a través de diversas arterias y redes de comunicación. Si tenemos algo comprobado a través de la lectura de las miles de páginas de la prensa en toda América, son sus relaciones y conexiones entre diversas regiones y espacios públicos. Por ejemplo, el caso del abogado bogotano Fernando López Aldana que en 1811 publicó El Diario Secreto de Lima como un papel manuscrito y clandestino, ante la ausencia de la libertad de imprenta, para llevar adelante la libertad a los pueblos oprimidos del Perú y socavar con la autoridad política española en la capital del virreinato peruano ${ }^{76}$. En ese sentido, difundió su Diario Secreto de mano en mano y de boca en boca, sugiriendo al apoyo de los demás escritores públicos y la formación de una sociedad filantrópica en 1812 cuando redactara e imprimiera El Satélite del Peruano. Lo interesante de El Diario Secreto de Lima estuvo en las diversas redes de comunicación que construyó a partir de su circulación por múltiples espacios y regiones de América como: Cuzco, Trujillo, Arequipa, Puno, el Alto Perú, Buenos Aires, Santiago de Chile, etc. Pero esta difusión se plasmó cuando El Diario Secreto se llegó a imprimir en las páginas de La Gaceta de Buenos Aires en 1811. El impreso clandestino de López Aldana alcanzó nivel internacional y a través de La Gaceta rioplatense pudo difundirse en toda América. La temática del impreso mantuvo una relación con los ideales de los revolucionarios jacobinos de Buenos Aires y López Aldana se convirtió en el agente encubierto de los rebeldes desde la coyuntura de Cádiz. Otro punto importante en el caso del autor de El Diario Secreto fue la publicación del Satélite del Peruano en 1812 y la catalogación que hizo el propio virrey Abascal del periódico como el papel más incendiario que ha salido de las prensas de esta ciudad. La construcción de las diversas redes y arterias de comunicación de El Satélite del Peruano se percibió cuando periódicos de Buenos Aires y de Santiago de Chile hicieron eco de sus argumentos y los reimprimieron en diversos números entre 1812 y 1813. La Aurora de Chile insertó en sus páginas de junio de 1812 parte de la introducción de El Satélite del Peruano en donde López Aldana defendió la publicación del Peruano y los ataques de los contrarrevolucionarios realistas y las artimañas

76 Daniel Morán y Wilder Calderón, La revolución del impreso, 85-108. 
del virrey por limitar la libertad de imprenta en el Perú77. Igualmente, en números anteriores, La Aurora reimprimió fragmentos del periódico El Peruano referente a los discursos de los diputados en las Cortes de Cádiz y los debates sobre la libertad de imprenta y la inquisición ${ }^{78}$. La misma tendencia lo tuvo La Gaceta de Buenos Aires en 1812 cuando informó la publicación de El Satélite del Peruano: "también se advierte en los periódicos limenses un aire de libertad tan extraño como el silencio con que se tolera por el visir. En la introducción del periódico que se publica con el título de El Satélite del Peruano dicen sus autores: por patria entendemos toda la vasta extensión de ambas Américas"79. Fernando López Aldana estuvo presente en una diversidad de redes y arterias de comunicación en los tiempos de las Cortes de Cádiz y muy vinculado a los grupos de poder revolucionarios, esta última idea se materializó con mayor fuerza con la llegada de San Martín al Perú y la difusión de una multitud de periódicos donde el autor de El Diario Secreto pudo participar activamente como Los Andes Libres de 1821 y en El Correo Mercantil, Político y Literario de 1821-1824.

En el caso de la prensa de Chile el escritor público más importante que realizó conexiones y canales de comunicación con diversas publicaciones extranjeras y de gran parte de América fue Camilo Henríquez. A través de La Aurora de Chile entre 1812 y 1813, El Monitor Araucano en 1813 y 1814, y en los últimos números de El Semanario Republicano de 1813 y 1814, Henríquez copó la esfera pública de la prensa en Santiago de Chile de la Patria Vieja. Por ejemplo, hemos advertido cómo La Aurora de Chile reprodujo informaciones de periódicos peruanos como El Peruano y El Satélite del Peruano de 1812, además, es evidente que tanto en La Aurora como en El Monitor Araucano, Camilo Henríquez reprodujo muchas noticias y partes oficiales del gobierno revolucionario de Buenos Aires que eran difundidas en su Gaceta oficial. La noticia de la celebración de un aniversario más de la revolución de mayo publicada en La Gaceta de Buenos Aires fue reimpresa en La Aurora de Chile: "El 25 de mayo celebró esta capital con pompa, y dignidad el día de su nacimiento glorioso de la patria, el aniversario de su redención política, y la época gloriosa de su

$77 \quad$ La Aurora de Chile, № 18, Santiago, jueves 11 de junio de 1812.

78 La Aurora de Chile, № 15, Santiago, jueves 21 de mayo de 1812.

79 La Gaceta Ministerial del Gobierno de Buenos Aires, № 5, viernes 8 de mayo de 1812. 
libertad civil"80. En El Monitor Araucano de 1813 también se difundieron comunicaciones de otros papeles públicos: "Por el Conciso de 9 de marzo, inserto en la Ministerial de Buenos Aires, se sabe lo siguiente: Se ha abolido en Espańa el Tribunal de la Inquisición" "11, y, "acaba de llegar el correo de Buenos Aires de 16 de julio. Todo va bien: la causa de la libertad vuela prósperamente todos sus pasos son felicidades" ${ }^{\prime 2}$. Incluso, en El Semanario Republicano de 1814, Camilo Henríquez, afirmó: "por correo de Buenos Aires no hemos tenido noticias positivas de Europa porque no se habían recibido papeles públicos [...] un caballero inglés residente en Buenos Aires dice: las noticias de Europa son en verdad muy grandes" La labor periodística de Henríquez después de su experiencia en la Patria Vieja y de su exilio luego de la reconquista realista en la batalla de Rancagua en octubre de 1814, prosiguió en la Buenos Aires revolucionaria con las Observaciones acerca de algunos asuntos útiles de 1815 y El Censor de 1817 hasta 1819, reemplazando a Antonio José Valdés ${ }^{84}$. Efectivamente, Camilo Henríquez pudo en su larga labor de escritor público relacionarse con el poder político y ampliar las redes y arterias de comunicación a través de un conjunto amplio de intercambios con los papeles públicos de toda América y Europa.

Finalmente, si buscamos un personaje y escritor público representativo del espacio rioplatense y que pueda conectar su experiencia con el itinerario de aquella capital, de Santiago de Chile y Lima en los tiempos de la independencia sería Bernardo de Monteagudo. Desde sus primeros escritos en La Gaceta de Buenos Aires de 1811 y 1812, la edición completa de Mártir o Libre de 1812 y la dirección de El Grito del Sud de 1812 y 1813, Monteagudo dejó bien en claro sus propuestas políticas e ideológicas apostando por la independencia y la revolución ${ }^{85}$. En Mártir o Libre señaló:

"La sagrada tea de la LIBERTAD arde ya por toda la América: podrá quizá un déspota aventurero o un desnaturalizado parricida apagarla en alguna pequeña parte con las lágrimas y la sangre de

80 La Aurora de Chile, N²2, Santiago, jueves 9 de julio de 1812.

81 El Monitor Araucano, $N^{\circ}$ 41, Santiago de Chile, sábado 10 de julio de 1813.

82 El Monitor Araucano, $N^{\circ}$ 52, Santiago de Chile, jueves 5 de agosto de 1813.

83 El Semanario Republicano, N 11, Santiago de Chile, sábado 8 de enero de 1814.

84 Óscar Urquiza, La cultura de Buenos Aires, 23.

85 Silvana Carozzi, Las filosofías de la revolución, 195-198; y, Daniel Morán, Batallas por la legitimidad, 97. 
nuestros mismos hermanos: pero las cenizas de su ruina no harán más que ocultar el fuego secreto que tarde o temprano ha de devorar a los opresores en su periódica explosión" $"$.

Fue en El Grito del Sud donde Monteagudo advirtió la importancia de la ilustración, la instrucción pública y el papel de los escritores públicos: "En un gobierno tempestuoso erigido entre las convulsiones de una revolución, nada puede prosperarle mejor, que el fomento de las letras y de la instrucción pública. La influencia de las luces del ingenio, y de las ciencias, es de algún modo más fuerte, que la de armas, de la autoridad, y del ejemplo" ${ }^{87}$. Como reconoció Noemí Goldman, Monteagudo fue, después de Moreno y Castelli, el único revolucionario que sobrevivió a la revolución de mayo y que llegó al Perú con el ejército libertador de San Martín. En ese trayecto participó en los asuntos políticos y en la publicación de diversos papeles públicos como fue el caso de El Censor de la Revolución en 1820 en Santiago de Chile y, en territorio peruano, dirigió El Pacificador del Perú en 1821 y auspició, como ministro del protectorado, múltiples periódicos limeños. Precisamente, en el prospecto de El Pacificador del Perú señaló:

"nosotros no necesitamos ofender el decoro público para combatir a los enemigos de la justicia: si ellos abusan de la Prensa de Lima, si en sus escritos predomina el carácter de la frivolidad, de la intemperancia y de la inverosimilitud, nuestra conducta mostrará la diferencia de la causa que defendemos, y nos degradaríamos en envidiar el triunfo que puedan obtener por aquellos medios [...] si los editores de Lima fulminan rayos contra la causa de los patriotas, guárdense de que ellos caigan sobre sus mismas cabezas, y que cuando en su despecho apelan a las mismas armas que nosotros para inclinar a su favor la opinión pública, el efecto sea diametralmente opuesto a sus miras" 88 .

Indudablemente, la participación de los escritores públicos en el escenario periodístico, su relación con el poder político y la influencia que ocasiona-

86 Mártir o Libre, $\mathrm{N}^{\circ}$ 5, Buenos Aires, lunes 27 de abril de 1812.

87 El Grito del Sud, N 7 , Buenos Aires, martes 25 de agosto de 1812.

88 Prospecto de El Pacificador del Perú, Lima-Huaura, de abril de 1821. 
ron en el debate público cumplieron un papel clave. Sus escritos construyeron y cubrieron una amplia red de espacios públicos y canales de comunicación como hemos podido apreciar en todo este capítulo y, de forma puntual, en las figuras de Fernando López Aldana, Camilo Henríquez y Bernardo de Monteagudo. Entonces, el poder de la prensa y su impacto en la sociedad solamente pudo advertirse a partir del análisis de los discursos políticos contenidos en los periódicos, el contexto en que se produjeron y sus vinculaciones con los intereses de los grupos en conflicto. Además, de la construcción de un conjunto de arterias de comunicación y espacios públicos de sociabilidad, donde el debate y la discusión política fue algo constante y el tema central de reflexión en la formación de la opinión pública moderna, en plena coyuntura de la revolución y las guerras de la independencia.

\section{Bibliografía}

\section{Fuentes primarias}

El Diario Secreto de Lima, 1811.

El Investigador del Perú, Lima, 1813-1814.

La Gaceta del Gobierno de Lima, 1810-1814.

El Sol del Perú, Lima, 1822.

Los Andes Libres, Lima, 1821.

El Pacificador del Perú, Lima-Barranca, 1821.

La Abeja Republicana, Lima, 1822-1823.

Nuevo Día del Perú, Trujillo, 1824.

El Correo de Comercio, Buenos Aires, 1810.

La Gaceta de Buenos Aires, 1810-1812.

Mártir o Libre, Buenos Aires, 1812.

El Grito del Sud, Buenos Aires, 1812.

El Censor, Buenos Aires, 1816.

La Prensa Argentina, Buenos Aires, 1815.

La Aurora de Chile, Santiago de Chile, 1812-1813.

El Monitor Araucano, Santiago de Chile, 1813-1814.

El Semanario Republicano, Santiago de Chile, 1813.

Viva El Rey. La Gaceta del Gobierno de Chile, 1814. 
El Chileno, Santiago de Chile, 1818.

El Censor de la Revolución, Santiago de Chile, 1820.

Archivo Arzobispal de Lima. Junta Eclesiástica de Purificación. "Documentos relacionados al expediente de purificación de don José Joaquín Larriva”, 1822.

De Larriva José Joaquín. Arenga que en presencia del Excmo. Señor Virrey Don José Fernando Abascal, pronunció por la Real Universidad de San Marcos en el besamanos del 27 de diciembre de 1812, el D. D. José Joaquín de Larriva. Lima: Imprenta de los huérfanos, por D. Bernandino Ruiz, 1813.

Memoria de Gobierno de José Fernando de Abascal y Sousa. Sevilla, tomo I, 1944.

\section{Fuentes secundarias}

Beltrán, Óscar. Historia del periodismo argentino. Buenos Aires: Editorial, 1943.

Bonilla, Heraclio (ed.). La Constitución de 1812 en Hispanoamérica y España. Bogotá: Universidad Nacional de Colombia, 2012.

Bragoni, Beatriz. San Martín. De soldado del Rey a héroe de la nación. Buenos Aires: Editorial Sudamericana, 2010.

Calvo, Nancy. "Voces en pugna. Prensa política y religión en los orígenes de la república argentina.” Hispania Sacra 122 (2008): 575-596.

Carozzi, Silvana. Las filosofías de la revolución. Mariano Moreno y los jacobinos rioplatenses en la prensa de Mayo, 1810-1815. Buenos Aires: Prometeo, 2011.

Castro Olivas, Jorge Luis. "Sociedades secretas y masonería en el proceso de emancipación peruano: la Logia Lautaro en el Perú". (tesis Mg. Historia-UNMSM, 2009).

Clément, Jean-Pierre. "Aproximación al Diario de Lima (1790-1793) y

a Jaime Bausate y Mesa, su autor.” El Argonauta Español 3 (2016).

Chartier, Roger. El mundo como representación. Estudios sobre historia cultural. Barcelona: Editorial Gedisa S.A., 1992.

Chassin, Joelle. "Lima, sus elites y la opinión durante los últimos tiempos de la colonia”. En Los espacios públicos en Iberoamérica, editado por 
François-Javier Guerra y Annick Lempériére. México: FCE, 1998, 241-269.

Chust, Manuel (ed.). Las independencias iberoamericanas en su laberinto. Valencia: Universidad de Valencia, 2010.

Couyoumdjian, Ricardo (coord.). Chile. Crisis imperial e independencia, 1808-1830. En Colección América Latina en la Historia Contemporánea, t. 1. Madrid: Fundación Mapfre-Editorial Taurus, 2010.

Cornejo, Carlos. "Las gacetas y el Semanario Crítico en el Perú colonial del siglo XVIII”. Cultura 26 (2012): 57-98.

Darnton, Robert. Los best sellers prohibidos en Francia antes de la revolución. Buenos Aires: FCE, 2008.

Díaz, César Luis. Comunicación y revolución, 1759-1810. Esfera y espacio público rioplatense. Periodismo, censura, prácticas y ámbitos de lectura. La Plata: Ediciones de Periodismo y Comunicación, 2012.

Garavaglia, Juan Carlos. Construir el estado, inventar la nación. El Río de la Plata, siglos XVIII-XIX. Buenos Aires: Prometeo, 2007.

Goldman, Noemí. "Libertad de imprenta, opinión pública y debate constitucional en el Río de la Plata (1810-1827).” Prismas 4 (2000): 9-20. Goldman, Noemí (ed.). Lenguaje y revolución: Conceptos políticos clave en el Río de la Plata, 1780-1850. Buenos Aires: Prometeo, 2008.

Goldman, Noemí. "Legitimidad, soberanía e independencia en el pensamiento de Mayo". En El pensamiento de los hombres de mayo, compilado por, Ricardo Tito. Buenos Aires: Editorial Ateneo, 2009.

Guerra, François-Xavier. Modernidad e independencias. Madrid: Editorial MAPFRE, S.A., 1992.

Guerra, François-Xavier. "Voces del pueblo. Redes de comunicación y orígenes de la opinión en el mundo hispánico (1808-1814)”. Revista de Indias vol. LXII, no 225, mayo-agosto (2002): 357-384.

Martínez Riaza, Ascensión. La prensa doctrinal en la independencia de Perú, 1811-1824. Madrid: Ediciones Cultura Hispánica-Instituto de Cooperación Iberoamericana, 1985.

Mc Evoy, Carmen. "De la comunidad retórica al Estado-Nación: Bernardo Monteagudo y los dilemas del republicanismo en América del Sud, 1811-1822". En Convivencia y buen gobierno: nación, nacionalismo y democracia en América Latina, compilado por, José Nun y 
Alejandro Grimson. Buenos Aires: Edhasa, 2006, 59-86.

Molina, Eugenia. El poder de la opinión pública. Trayectos y avatares de una nueva cultura política en el Río de la Plata, 1800-1852. Santa Fe: Universidad Nacional del Litoral, 2009.

Montoya, Gustavo. La independencia del Perú y el fantasma de la revolución. Lima: IEP-IFEA, 2002.

Morán, Daniel y María Aguirre. Prensa política y educación popular en la independencia de América Latina. Lima: Fondo Editorial de la Universidad de Ciencias y Humanidades, 2015.

Morán, Daniel y Wilder Calderón. La revolución del impreso. La prensa y el lenguaje político en la independencia. Lima: Fondo Editorial de la Universidad Peruana Simón Bolívar, 2014.

Morán, Daniel. Batallas por la legitimidad. La prensa de Lima y de Buenos Aires durante las guerras de independencia. Lima: Fondo Editorial de la Universidad de Ciencias y Humanidades, 2013.

Morán, Daniel. "Construyendo al enemigo. La emergencia de identidades políticas y las representaciones del otro en la prensa hispanoamericana en los tiempos de la Independencia.” Temas Americanistas 39 (2017): 113-145.

Morán, Daniel. “¿Educando a los súbditos? Modernidad y tradición en una época revolucionaria. El Investigador [del Perú] (1813-1814)”. Revista Historia Crítica 41 (2010): 110-133.

Morán, Daniel. "Reformistas, fidelistas y contrarrevolucionarios. Prensa, poder y discurso político en Lima durante las Cortes de Cádiz, 18101814”. (tesis Lic. Historia-UNMSM, 2008).

Peralta Ruiz, Víctor. La independencia y la cultura política peruana, 18081821. Lima: IEP- Fundación M. J. Bustamante De la Fuente, 2010. Peralta Ruiz, Víctor. En defensa de la autoridad. Política y cultura bajo el gobierno del virrey Abascal. Perú, 1806-1816. Madrid: CSIC-Instituto de Historia, 2002.

Pérez Guerra, Carlos. "La importancia de los periódicos de la Patria Vieja para el movimiento revolucionario nacional. El aporte de los escritos de Camilo Henríquez y Antonio José Irisarri”. (tesis Lic. Historia-Universidad de Chile, 2005).

Piñeiro, Armando. El periodismo porteño en la época de la independencia. Buenos Aires: ANP, 2008. 
Porras Barrenechea, Raúl. Los ideólogos de la emancipación. Lima: Editorial Milla Batres, 1974.

Rebollero, Antonia. "La cultura”. En Chile. Crisis imperial e independencia, 1808-1830, coordinado por Ricardo Couyoumdjian, Colección América Latina en la Historia Contemporánea, t. 1. Madrid: Fundación Mapfre-Editorial Taurus, 2010, 223-276.

Rosas Lauro, Claudia. Del trono a la guillotina: El impacto de la revolución francesa en el Perú (1789-1808). Lima: PUCP-IFEA-Embajada de Francia, 2006.

San Francisco, Alejandro. "La vida política”, En Chile. Crisis imperial e independencia, 1808-1830, coordinado por Ricardo Couyoumdjian, Colección América Latina en la Historia Contemporánea, t. 1. Madrid: Fundación Mapfre-Editorial Taurus, 2010, 39-88.

Soto, Ángel (ed.). Entre tintas y plumas. Historia de la prensa chilena del siglo XIX. Santiago: Universidad de los Andes, 2004.

Subrahmanyam, Sanjay. "Connected Histories: Notes towards a Reconfiguration of Early Modern Eurasia”, Modern Asian Studies, Vol. 31, No. 3 (1997): 735-762.

Tito, Ricardo (comp.). El pensamiento de los hombres de Mayo. Buenos Aires: Editorial Ateneo, 2009.

Urquiza, Óscar. La cultura de Buenos Aires a través de su prensa periódica, 1810-1820. Buenos Aires: Eudeba, 1972.

Vázquez, Graciana. Revolución y discurso. Un portavoz para la integración hispanoamericana: Bernardo Monteagudo (1809-1825). Buenos Aires: La Isla de la Luna, 2006.

Para citar este artículo: Morán Ramos, Luis Daniel. "Críticos y rebeldes en América del Sur. Prensa, redes de interacción y debate político en la formación de la opinión pública moderna en tiempos de la independencia (1810-1822)", Historia Caribe Vol. XIV No. 34 (Enero-Junio 2019): Pag.19-54. DOI: http://dx.doi.org/10.15648/hc.34.2019.1 